\title{
Angelika Kaczmarczyk
}

Uniwersytet Ekonomiczny we Wrocławiu

e-mail: angelika.kaczmarczyk@ue.wroc.pl

\section{AKTYWA TRWAŁE PRZEZNACZONE DO SPRZEDAŻY W ASPEKCIE ZASADY WIERNEGO \\ I RZETELNEGO OBRAZU}

\section{NON-CURRENT ASSETS HELD FOR SALE IN TERMS OF TRUE AND FAIR VIEW}

DOI: $10.15611 /$ pn.2018.513.16

JEL Classification: M41

\begin{abstract}
Streszczenie: Aktywa przeznaczone do sprzedaży są pozycją wykazywaną odrębnie według Międzynarodowych Standardów Rachunkowości. Jeśli podmiot gospodarczy planuje zbyć dane aktywa trwałe, nie powinny być one wyceniane w taki sam sposób jak środki trwałe. Polskie przepisy prawa bilansowego nie poruszają problemu aktywów trwałych przeznaczonych do sprzedaży. Celem artykułu jest próba udzielenia odpowiedzi na pytanie, jak i czy w ogóle w sprawozdaniu finansowym sporządzanym zgodnie z polskim prawem bilansowym zaprezentować aktywa trwałe przeznaczone do sprzedaży, tak by spełniona była jedna z podstawowych zasad rachunkowości - zasada wiernego i rzetelnego obrazu. Dla realizacji powyższego celu posłużono się następującymi metodami badawczymi: analiza literatury, analiza aktów prawnych z badanego zakresu, analiza sprawozdań finansowych, dedukcja.
\end{abstract}

Słowa kluczowe: aktywa trwałe, sprzedaż, wycena.

Summary: Non-current assets held for sale are disclosed separately in IFRS. Polish balance sheet law does not address the problem of non-current assets held for sale. The purpose of this article is to try to answer the question: how to present in the financial statements non-current assets held for sale to comply with the principle of true and fair view. The following research methods were used to achieve the goal: literature analysis, analysis of legal acts from the studied scope, analysis of financial statements, deduction.

Keywords: non-current assets, sale, valuation.

\section{Wstęp}

Problem aktywów trwałych przeznaczonych do sprzedaży reguluje Międzynarodowy Standard Sprawozdawczości Finansowej nr 5 (MSSF 5) Aktywa trwałe przeznaczone do sprzedaży oraz działalność zaniechana. MSSF 5 został wydany w 2004 r. 
i zastąpił MSR 35 Działalność w trakcie zaniechania. Obecny standard zmienił przepisy w zakresie kwalifikacji i prezentacji działalności zaniechanej i przyjął rozwiązania zbliżone do amerykańskiego standardu SFAS 144 Ujmowanie aktywów o dtugim okresie użytkowania. Jednostka kwalifikuje dany składnik aktywów trwałych (np. środki trwałe czy nieruchomości) do sprzedaży, jeśli jego wartość bilansowa zostanie odzyskana drogą sprzedaży. Nie będzie dalej użytkowana ani nie zostanie przeznaczona do likwidacji. Składnik aktywów trwałych może zostać zakwalifikowany do sprzedaży, jeśli:

- jest zdatny do natychmiastowej sprzedaży w obecnym stanie z uwzględnieniem warunków, jakie są normalnie przyjęte przy sprzedaży tego typu aktywów, oraz

- dojście sprzedaży do skutku jest wysoce prawdopodobne.

Pośród największych grup kapitałowych notowanych na Giełdzie Papierów Wartościowych w Warszawie, w badaniach prowadzonych przez G. Voss i P. Pre-

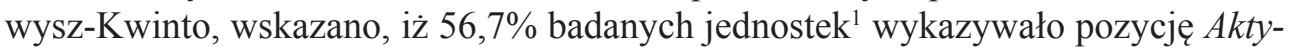
wa trwate przeznaczone do sprzedaży [Prewysz-Kwinto, Voss 2016, s. 180]. Analiza powyższych informacji wskazała, iż największy odsetek podmiotów prezentujących aktywa przeznaczone do sprzedaży dotyczył branży chemicznej i paliwowej (100\%), finansowej $(92 \%)$ oraz energetycznej $(80 \%)$. Brak takich aktywów występował w jednostkach z branży motoryzacyjnej oraz spożywczej.

$\mathrm{Na}$ gruncie polskich regulacji prawnych problem aktywów trwałych przeznaczonych do sprzedaży nie istnieje. Przedsiębiorstwa sporządzające sprawozdania finansowe zgodnie z krajowymi regulacjami prawnymi nie znajdują odpowiednich norm, które regulowałyby kwestie aktywów trwałych, które jednostka zamierza zbyć w krótkim czasie. Z pewnością odpowiednią częścią sprawozdania finansowego do wykazania takich aktywów jest informacja dodatkowa. Wycena na dzień bilansowy pozostaje jednak taka sama jak w przypadku środków trwałych, które jednostka zamierza nadal użytkować.

\section{Kontynuacja działania w polskich i międzynarodowych regulacjach prawnych}

Zasada kontynuacji działania jest jedną z podstawowych zasad sprawozdawczości finansowej. Jednostki gospodarcze sporządzają sprawozdanie finansowe przy założeniu, że będą kontynuowały działalność gospodarczą w najbliższym czasie. Na gruncie krajowym definicje tej zasady można znaleźć w ustawie o rachunkowości [Ustawa o rachunkowości 2013]. Przepisy tejże ustawy stanowią, iż przy stosowaniu przyjętych zasad (polityki) rachunkowości przyjmuje się założenie, że jednostka będzie kontynuowała w dającej się przewidzieć przyszłości działalność w niezmniej-

${ }^{1}$ Badanie dotyczyło jednostek wchodzących w dniu 15 stycznia 2015 r. w skład dwóch indeksów giełdowych: WIG-20 oraz WIG-40, najwięcej reprezentowało branżę finansową $(21,7 \%)$ oraz energetyczną $(8,3 \%)$, chemiczną i paliwową $(8,3 \%)$, handel detaliczny i hurtowy $(8,3 \%)$. 
szonym istotnie zakresie bez postawienia jej w stan likwidacji lub upadłości, chyba że jest to niezgodne ze stanem faktycznym lub prawnym. Ustawa o rachunkowości nie zawiera żadnych wskazówek, jak tę zdolność zweryfikować. Stanowi tylko, iż ustalając zdolność jednostki do kontynuowania działalności, kierownik jednostki uwzględnia wszystkie informacje dostępne na dzień sporządzenia sprawozdania finansowego dotyczące dającej się przewidzieć przyszłości, obejmującej okres nie krótszy niż jeden rok od dnia bilansowego. Są to sformułowania dość ogólne. Złożenie oświadczenia o kontynuacji działalności pociąga za sobą określone konsekwencje w zakresie wyceny. Jednostka może stosować do wyceny art. 28 ustawy o rachunkowości. Brak kontynuacji działania powoduje obowiązek wyceny aktywów w możliwych do uzyskania cenach sprzedaży netto nie wyższych od ich cen nabycia lub kosztów wytworzenia, przy czym należy dokonać ich pomniejszenia o odpisy amortyzacyjne oraz odpisy aktualizujące.

W polskich regulacjach prawnych w art. 47 ustawy o rachunkowości wprowadzono zapis zobowiązujący jednostki, które przewidują zaprzestanie określonego zakresu działalności mającego wpływ na przychody i koszty przyszłych okresów do odrębnego ich wykazania jako działalności zaniechanej. Jednostka deklaruje zamiar kontynuacji działania, ale koszty i przychody związane z działalnością zaniechaną są prezentowane odrębnie. Aktywa, które jednostka zamierza zbyć, są amortyzowane planowo, a zamiar sprzedaży nie wpływa na zmianę metod i stawek amortyzacji. Ponadto w bilansie nie ujawnia się tych aktywów odrębnie. Zgodnie z zasadą istotności informacja o zaniechaniu działalności jest z pewnością informacją istotną, której pominięcie może wpłynąć na decyzje podejmowane przez użytkowników informacji sprawozdawczej. Dodatkowo należy zwrócić uwagę na art. 50 ust. 1 ustawy o rachunkowości, który zezwala na wykazanie informacji ze szczegółowością większą aniżeli w załączniku do ustawy, jeśli wynika to ze specyfiki lub potrzeb jednostki [Ustawa o rachunkowości 2013]. Informacje o działalności zaniechanej powinny zostać wykazane w opisowej części sprawozdania finansowego - informacji dodatkowej.

Według MSSF 5 działalność zaniechana stanowi element jednostki gospodarczej, który został zbyty lub został zakwalifikowany do sprzedaży oraz:

- stanowi odrębną, ważną dziedzinę działalności lub geograficzny obszar działalności,

- jest częścią pojedynczego, skoordynowanego planu zbycia odrębnej, ważnej dziedziny działalności lub geograficznego obszaru działalności lub

- jest jednostką zależną nabytą wyłącznie z zamiarem jej odsprzedaży.

Aktywami przeznaczonymi do zbycia mogą być: części składowe jednostki, grupy do zbycia lub pojedyncze aktywa jednostki.

Warunkami niezbędnymi do uznania aktywów jako przeznaczonych do sprzedaży są:

- składnik aktywów jest dostępny do natychmiastowej sprzedaży,

- jego sprzedaż jest wysoce prawdopodobna. 
Oba warunki muszą być spełnione łącznie. Rysunek 1 prezentuje warunki, w których sprzedaż jest wysoce prawdopodobna.

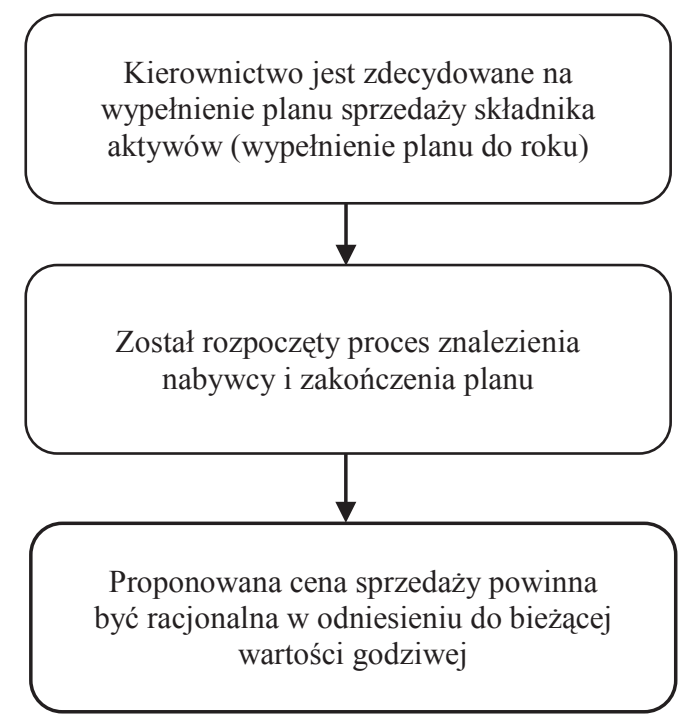

Rys. 1. Warunki wystąpienia prawdopodobieństwa sprzedaży

Źródło: opracowanie własne.

Należy zaznaczyć, iż standard przewiduje możliwość wydłużenia czasu realizacji planu sprzedaży składnika aktywów trwałych powyżej jednego roku. Mogą zaistnieć pewne okoliczności lub zdarzenia, które wydłużają ten okres, nie jest to jednak równoważne z wyłączeniem danego składnika aktywów z grupy przeznaczonych do sprzedaży. Jeśli okoliczności lub zdarzenia są poza kontrolą jednostki, a jednostka nadal przestrzega wykonania planu sprzedaży - aktywa są traktowane jako przeznaczone do sprzedaży.

Jednostka nie może kwalifikować do sprzedaży aktywów, które mają przestać być użytkowane lub są czasowo wyłączone z użytkowania. Wartość bilansowa tych aktywów musi zostać odzyskana przede wszystkim w drodze sprzedaży, a nie poprzez ich dalsze wykorzystanie. Do zakwalifikowania aktywów trwałych do sprzedaży nie wystarczy sam zamiar ich zbycia, musi zostać podjęta stosowna decyzja na odpowiednim szczeblu zarządzania oraz muszą zostać podjęte konkretne działania. Czasowe zaprzestanie użytkowania nie jest przesłanką uznania aktywów trwałych jako przeznaczonych do sprzedaży. 


\section{Zasada wiernego i rzetelnego obrazu a prezentacja aktywów przeznaczonych do sprzedaży na gruncie polskiego prawa bilansowego}

Należy zgodzić się ze stwierdzeniem T. Cebrowskiej, iż celem sprawozdania finansowego jest nie tylko przedstawienie jasnego i rzetelnego obrazu, ale także zaspokojenie potrzeb informacyjnych jego odbiorców [Cebrowska 1994, s. 31]. Koncepcja wiernej prezentacji polega na wyborze i przyjęciu przez jednostkę takich rozwiązań, które uwzględniając specyfikę jednostki, zapewniają wymaganą jakość sprawozdań finansowych [Gierusz 2011, s. 36]. Zasada ta ma podstawowe znaczenie dla wiarygodności sprawozdania finansowego konkretnego przedsiębiorstwa [Messner 2011, s. 19]. M. Gmytrasiewicz twierdzi, iż koncepcja wiernego i rzetelnego obrazu stanowi swego rodzaju antidotum na niedoskonałości norm rachunkowości w zderzeniu z praktyką gospodarczą [Gmytrasiewicz 2006, s. 16]. Rola tej koncepcji jest bezsporna. W Wielkiej Brytanii została uznana za zasadę over ride, zgodnie z którą standardy brytyjskie dopuszczają możliwość naruszenia regulacji ustawowych na rzecz uzyskania obrazu możliwie obiektywnego i prawdziwego [Gierusz 2011, s. 40].

Artykuł 28 ustawy o rachunkowości zawiera postanowienia dotyczące wyceny poszczególnych aktywów i pasywów na dzień bilansowy. Rzeczowe aktywa trwałe należy wyceniać według ceny nabycia (kosztu wytworzenia) pomniejszone o odpisy umorzeniowe oraz odpisy z tytułu utraty wartości. Nie ma tam jednak mowy o sytuacji, w której jednostka planuje je zbyć. Jak zaawizowano na początku, jednostka może zgłosić brak kontynuacji działania, ale to dotyczy całej działalności lub znaczącej jej części.

Czy brak prezentacji aktywów trwałych przeznaczonych do sprzedaży nie stoi w sprzeczności z zasadą wiernego i rzetelnego obrazu jednostki? Odbiorca informacji sprawozdawczej nie ma możliwości zapoznania się z wyceną takiego środka trwałego. Z pewnością informacje o zamiarze zbycia środków trwałych powinny zostać zawarte w informacji dodatkowej, ale w jakim zakresie, to leży w gestii jednostki. W KSR nr 11 zaleca się minimalny zakres informacji na temat środków trwałych prezentowanych i ujawnianych w postaci:

- „Zysku/Straty z tytułu rozchodu niefinansowych aktywów trwałych (rachunek zysków i strat),

- zasad polityki rachunkowości stosowanych przez jednostkę w stosunku do środków trwałych i ich amortyzacji (wprowadzenie do sprawozdania finansowego),

- dodatkowych informacji, takich jak: wartość rynkowa lub inaczej określona wartość godziwa środków trwałych, o ile różni się ona znacząco od wykazanej wartości księgowej, wartość początkowa w pełni zamortyzowanych środków trwałych, wartość księgowa czasowo nieużywanych środków trwałych [KSR 11 2017].

Należy zaznaczyć, iż jednostki gospodarcze mogą korzystać z zapisów zawartych w Międzynarodowych Standardach Rachunkowości w sytuacji, gdy nie są one sprzeczne z krajowymi regulacjami prawnymi. MSSF 5 reguluje metody wyceny 
oraz prezentacji aktywów trwałych przeznaczonych do sprzedaży. Aktywa przeznaczone do sprzedaży należy wycenić według wartości bilansowej lub wartości godziwej pomniejszonej o koszty sprzedaży w zależności od tego, która z nich jest niższa. W momencie gdy składnik rzeczowych aktywów trwałych zostaje przeznaczony do zbycia, należy zaprzestać jego amortyzacji. Ustalenie wartości godziwej następuje po zakwalifikowaniu składnika aktywów do sprzedaży. Jeśli wartość godziwa pomniejszona o koszty sprzedaży jest niższa od jego wartości bilansowej, w rachunku zysków i strat rozpoznaje się stratę. W przypadku odwrotnym, gdy wartość godziwa pomniejszona o koszty sprzedaży jest wyższa od wartości bilansowej, zysku nie wykazuje się, gdyż wycena pozostaje na poziomie wartości bilansowej. Aktywa spełniające kryteria aktywów przeznaczonych do sprzedaży powinny być ujmowane oddzielnie w bilansie, a skutki działalności zaniechanej muszą być ujmowane oddzielnie w rachunku zysków i strat. Aktywa trwałe po zakwalifikowaniu do sprzedaży nie są przenoszone do aktywów obrotowych, ale muszą być wykazane w oddzielnej pozycji.

Czy powyższe rozwiązania można przenieść na grunt polskiego wzoru bilansu oraz rachunku zysków i strat? Brak w nich powyższych pozycji. Zgodnie jednak z art. 50 ustawy o rachunkowości informacje zawarte w sprawozdaniu finansowym mogą zostać wykazane ze szczegółowością większą niż określona w załącznikach do ustawy, jeśli wynika to z potrzeb lub specyfiki jednostki. Aktywa przeznaczone do sprzedaży nie powinny pozostać w pozycji ,rzeczowe aktywa trwałe”, gdyż nie spełniają ich definicji. Stosowanie do art. 3 ustawy o rachunkowości aktywa obrotowe to część aktywów jednostki, które w przypadku aktywów rzeczowych są przeznaczone do zbycia lub zużycia w ciągu 12 miesięcy od dnia bilansowego lub w ciągu normalnego cyklu operacyjnego właściwego dla danej działalności, jeśli trwa on dłużej niż 12 miesięcy. Zgodnie z zasadą rzetelnego obrazu jednostka powinna wyodrębnić środki trwałe przeznaczone do sprzedaży i zaprezentować je w odrębnej pozycji w aktywach obrotowych. Pozostawienie środków trwałych w pozycji „rzeczowe aktywa trwałe” w aktywach trwałych oznacza, iż jednostka zamierza dalej użytkować je w swojej działalności operacyjnej. Z kolei towary (nabyte w celu dalszej odsprzedaży) czy produkty gotowe, czy materiały (wytworzone czy przetworzone przez jednostkę) też nie są do końca odpowiednimi pozycjami do prezentowania aktywów trwałych przeznaczonych do sprzedaży. Kwestia klasyfikacji jest wobec tego dyskusyjna, przy czym przeniesienie do aktywów obrotowych będzie zgodne z zasadą jasnej, rzetelnej i zgodnej z treścią ekonomiczną prezentacji sytuacji finansowej jednostki. Powyższy schemat postępowania będzie dodatkowo zgodny z art. 10 ustawy o rachunkowości, który zezwala na korzystanie z Międzynarodowych Standardów Rachunkowości (o ile nie są sprzeczne z polskim prawem bilansowym). Zgodnie z MSSF 5 jednostka powinna zaprzestać amortyzacji takiego środka trwałego.

Za wyodrębnieniem aktywów przeznaczonych do sprzedaży z rzeczowych aktywów trwałych przemawia także artykuł 4 ust. 1 ustawy o rachunkowości [Ustawa 
o rachunkowości 2013]. W celu rzetelnego i jasnego przedstawienia sytuacji majątkowej i finansowej oraz wyniku finansowego jednostka zobowiązana jest przedstawić wszelkie dodatkowe informacje konieczne do spełnienia tego obowiązku w informacji dodatkowej. Dodatkowo kolejny artykuł zezwala na rezygnację z danego przepisu ustawy, jeśli nie pozwala on na rzetelne i jasne przedstawienie sytuacji jednostki. Pomimo iż aktywa trwałe przeznaczone do sprzedaży nie do końca mieszczą się w definicji zapasów, to wykazanie ich w aktywach obrotowych wydaje się bardziej zasadne niż pozostawienie ich w aktywach trwałych.

$\mathrm{Z}$ drugiej strony analiza sprawozdań finansowych ${ }^{2}$ wybranych podmiotów notowanych na polskiej giełdzie wskazuje, iż nie są to pozycje istotne w stosunku do całości aktywów. W tabeli 2 zaprezentowano udział procentowy wartości aktywów przeznaczonych do sprzedaży do wartości aktywów ogółem.

Tabela 1. Udział procentowy wartości aktywów przeznaczonych do sprzedaży do wartości aktywów

\begin{tabular}{|l|c|c|}
\hline \multicolumn{1}{|c|}{ Spółki } & Rok & Udział procentowy \\
\hline Tauron SA & 2014 & 3,9 \\
\hline Energa SA & 2014 & 0,64 \\
\hline Enea SA & 2014 & 0,087 \\
\hline Orlen SA & 2015 & 0,20 \\
\hline Grupa Azoty SA & 2015 & 0,008 \\
\hline Ciech SA & 2014 & 0,084 \\
\hline
\end{tabular}

Źródło: opracowanie własne na podstawie sprawozdań finansowych wybranych spółek.

Na podstawie tabeli 2 należy wywnioskować, iż nie jest to znacząca pozycja wartościowa w całości sumy bilansowej. Tylko spółka Tauron wyceniła aktywa trwałe przeznaczone do sprzedaży aż na 1337705 tys., co stanowiło prawie 4\% wartości całej sumy bilansowej. W pozostałych spółkach udział ten nie przekroczył $1 \%$, co może wskazywać na brak istotności tej pozycji.

Przenosząc te rozważania na grunt polskich regulacji, można zaryzykować stwierdzenie, iż pozycja aktywa trwałe przeznaczone do sprzedaży może stanowić ważną informację dla odbiorcy informacji sprawozdawczej, ale tylko wówczas, jeśli spełniona jest zasada istotności.

\section{Zakończenie}

Rzeczowe aktywa trwałe przeznaczone do sprzedaży są przedmiotem odrębnego standardu na gruncie międzynarodowym. Zagadnienie to reguluje MSSF nr 5 Aktywa trwate przeznaczone do sprzedaży. Zgodnie z nim jednostka powinna sklasyfiko-

${ }^{2}$ Do analizy wybrano spółki, głównie z branży paliwowej, energetycznej i chemicznej, gdyż w tych branżach spółki wykazywały pozycje aktywa trwałe przeznaczone do sprzedaży (o czym wspomniano na początku artykułu). 
wać składnik aktywów trwałych przeznaczonych do sprzedaży, jeśli jego wartość bilansowa zostanie odzyskana (zrealizowana) drogą sprzedaży, a nie dalszego użytkowania. W polskich regulacjach prawnych problem ten został pominięty. Aktywa trwałe przeznaczone do sprzedaży są wykazywane w grupie rzeczowych aktywów trwałych w bilansie. Należy uznać to za pewne niedopatrzenie. Informacja o sprzedaży, czasami środków trwałych o dużej wartości, jest informacją istotną, która wpływa na decyzje użytkowników informacji sprawozdawczej. W sytuacji gdy wartość pozycji aktywa przeznaczone do sprzedaży jest nieistotna, można pominąć jej odrębną prezentację w sprawozdaniu finansowym.

Zasada wiernej i rzetelnej prezentacji sytuacji majątkowej i finansowej jednostki wymaga wyceny tych aktywów według Międzynarodowych Standardów Rachunkowości oraz prezentacji w aktywach obrotowych - zapasach, w przypadku braku odpowiedniej pozycji we wzorach bilansu do ustawy o rachunkowości.

\section{Literatura}

Cebrowska T., 1994, Dylematy polityki bilansowej, Prace Naukowe AE, nr 690, Wrocław.

Gierusz J., 2011, Koszty i przychody w świetle nadrzędnych zasad rachunkowości, ODDK, Gdańsk. Gmytrasiewicz M., 2006, Rachunkowość finansowa, Vademecum Rachunkowości, Difin, Warszawa.

Gmytrasiewicz M., 2011, Rachunkowość. Podstawowe założenia i zasady, Vademecum Rachunkowości, Difin, Warszawa.

Krajowy Standard Rachunkowości nr 11 „Środki trwałe”, Komunikat Ministra Rozwoju i Finansów z dnia 25 maja 2017, www.mf.gov.pl (dostęp: 24.04.2018).

Międzynarodowy Standard Sprawozdawczości Finansowej 5 Aktywa trwałe przeznaczone do sprzedaży, Dz.U. UE L320/405, www.polskiaudyt.pl (dostęp: 18.06.2017).

Messner Z., 2011, Rachunkowość finansowa w systemie informacji ekonomicznej, [w:] Rachunkowość finansowa z uwzględnieniem MSSF, Wydawnictwo Naukowe PWN, Warszawa.

Prewysz-Kwinto P., Voss G., 2016, Aktywa trwałe przeznaczone do sprzedaży w sprawozdaniach finansowych największych grup kapitałowych notowanych na GPW w Warszawie, Studia Ekonomiczne, Zeszyty Naukowe Uniwersytetu Ekonomicznego w Katowicach nr 268, Katowice.

Ustawa z 29 września 1994 r. o rachunkowości, Dz.U. Nr 14, poz. 114 ze zm. 